Jurnal Syntax Imperatif: Jurnal Ilmu Sosial dan Pendidikan

p-ISSN: 2721-2491 e-ISSN: 2721-2246

Vol. 1, No. 4, September 2020

\title{
Inovasi Pendidikan dalam Efektivitas Penerapan Kurikulum 2013
}

\author{
Redmon Windu Gumati \\ Sekolah Tinggi Ilmu Tarbiyyah (STIT) At-Taqwa Ciparay Kabupaten Bandung, \\ Indonesia \\ E-mail: redmon.windu@gmail.com
}

\begin{abstract}
Abstrak
Pendidikan merupakan masalah penting dan fundamental dalam kaitanya dengan pembangunan bangsa secara keseluruhan. Apalagi setelah diterapkannya Kurikulum 2013, pendidikan dituntut untuk dapat menanamkan perannya sebagai basis dan benteng tangguh yang menjaga serta memperkokoh etika moral bangsa. Dengan metode explanatory research dan pendekatan kualitatif, maka analisa data yang dipakai adalah teknik analisis inferensial (inferential analitic). Oleh sebab itu, Dalam penelitian ini diperoleh data bahwa seiring menggunakan kemajuan pada bidang pendidikan perlu adanya penemuan, yang secara perlahan-lahan sudah terjadi perubahan kerangka berpikir, metode, serta contoh pendidikan baru yang inovatif, seperti perubahan dari guru kepada siswa; keluarnya kesadaran bahwa informasi/pengetahuan dapat diakses lewat aneka macam cara serta media oleh peserta didik; teknologi pembelajaran yangt berbasis dari Teknologi dan Informasi mulai diterapkan; orientasi pendidikan yang melainkan bukan hanya dari pengembangan sumber daya manusia, tetapi dalam mengembangkan kapabilitas manusia; mendapat perkenalan dalam elearning; dari dependence ke independence; individual kepada team work oriented; serta large group ke small class. Hal ini selaras dengan menerapkan kurikulum 2013 (KURTILAS), yaitu konsep kurikulum yang diberikan kepada otonom yang besar dari kepada sekolah sebagai lembaga penyelenggaran pendidikan, baik swasta maupun pemerintah, untuk mengakomodir tuntutan masyarakat dalam meningkatkan kualitas, efisiensi dan pemerataan pendidikan.
\end{abstract}

Kata kunci: Inovasi; Efektifitas; Kurikulum 2013;

\section{Pendahuluan}

Istilah inovasi mengandung arti tindakan dalam menciptakan sesuatu yang baru dalam perubahan dengan menghasilkan gagasan dan pendekatan atau metode baru. Untuk membuat sesuatu yang baru, yang dibutuhkan lebih berdaya guna, tentu saja harus bertolak berasal apa yang ada. Selalu terdapat kata sulit untuk memulai dan menaikkan sesuatu dari yang belum ada (ex nihilo). Apalagi adanya kecenderungan dalam suatu globalisasi dan harapan untuk menyesuaikan tuntutan dalam kebutuhan beraspirasi bangsa Indonesia pada masa depan, yang akan membawa akibat dalam perubahan kebijakan, khususnya pada bidang pendidikan. Misi dalam pendidikan adalah untuk menghasilkan berbagain insan dan kompetitif terhadap perubahan dan kebutuhan stakeholders. (Wahyudin \& Kurniasih, Tatang Saripudin, n.d.)

Teknologi telah mengganti paras serta peran rakyat modern. sajian penemuan saat ini artinya multimedia menggunakan kombinasi teks, sound, animasi. Perubahan pada inovasi dapat berupa pergantian, perubahan, penambahan, penyusunan kembali, penghapusan, serta penguatan model hasil inovasi merupakan pembelajaran yang 
berbasis anti korupsi, Manajemen Sekolah/ Madrasah bersertifikasi ISO. (D Supriadi, 2002)

Penemuan dalam dunia pendidikan serta pembelajaran dilandasi oleh teknologi pendidikan serta dilandasi oleh teknologi pembelajaran. Pemahaman teknologi pembelajaran yaitu teknologi menjadi inspirasi serta merancang pembangunan dengan suatu proses pembelajaran yang dinilai berkualitas melalui pengukuran efektivitas serta efisiensi, dan akselerasi pencapaian perubahan sikap siswa atau masyarakat belajar. Didalam teori difusi penemuan penggunaan contoh secara konsisten untuk bagaimana suatu pembelajaran informasi baru dikomunikasikan ke public. Model berarti contoh, teladan, meniru, mengikuti jejak. Berdasarkan Mile (1973) karakteristik primer penemuan ialah: mempunyai kekhasan; unsur kebaruan; melalui acara yang terencana; serta mempunyai tujuan. Inovasi tidak begitu saja bisa diterima, tetapi terdapat perubahan-perubahan yang memerlukan persiapan dan waktu yang panjang. Kecepatan pelaksanaannya dapat tergantung pada kondisi sekolah serta kesiapannya bagi para pelaksana. Cepat maupun lambatnya inovasi, dapat diterima oleh masyarakat atau sekolah tergantung pada karakteristik tersebut. Salah satu inovasi yang dilakukan di sekolah adalah inovasi penggunaan bahasa asing di luar bahasa Indonesia di dalam pendidikan formal dan non formal, yaitu penggunaan Bahasa Inggris, Bahasa Perancis dan Bahasa Arab.

Pemerintah harus memberi dukungan dalam inovasi pendidikan ini, semisal melalui mekanisme memberi alokasi inovasi teknologi pembelajaran baik individual maupun kelompok. Beberapa inovasi bisa berbentuk simulasi, materi dalam sebuah video, tutorial dalam beberapa disiplin ilmu, role play (bermain peran) dalam ilmu-ilmu sosial dan perencanaan, serta editing program-program. Walaupun pada beberapa tahun yang lalu, dapat mengidentifikasikan perkembangan yang relatif lamban (very slow), karena semua pihak sudah menyadari bahwa inovasi di berbagai bidang pendidikan yang dapat memberikan suatu kontribusi kepada bangsa.(Silberman, 2009)

Bercermin pada Penelitian sebelumnya, semisal penelitian yang dilakukan oleh Pusat Pemuda Berbakat, di Johns Hopkins University, pada tahun 1994, menemukan 175 pemuda dalam merasakan konsekuensi yang positif menjadi 95\% dengan adanya inovasi pendidikan, meskipun melaporkan adanya beberapa konsekuensi negatif. Kurang dari $2 \%$ terdapat laporan adanya efek negatif. Temuan yang mengejutkan adalah bahwa sebagian besar yang dialami siswa merasa terinovasi dengan sifat yang positif, mengingat begitu urgen inovasi pendidikan, maka orang tua, pendidik, sekolah, dan pemerintah harus memberikan fasilitas untuk adanya inovasi ini. Walaupun ada laporan tentang adanya efek negatif, dalam penelitian tersebut telah kemukakan bahwa efek itu ada karena dampak dari kesulitan sosial, dan hal itu tidak menjadi dampak yang besar. Dalam penelitian itu juga, sangat direkomendasikan bahwa siswa, orang tua, dan pendidik mempertimbangkan manfaat dari adanya inovasi pendidikan.

Dalam membangun inovasi pendidikan yang terpenting ialah kemauan dan citacita pengajar untuk mengganti persepsi serta image pelajar sebagai suatu langkah pemaksaan menjadi kebutuhan, dengan cara membawa siswa menikmati sisi-sisi 
estetika serta kemenarikan dari suatu bahan ajar yang sedang dipelajarinya. Hal ini hanya bisa dilakukan Jika pengajar melakukan inovasi.

Semisal merubah kerangka berpikir pembelajaran memakai prinsip proses dalam pembelajaran yang selalu dihubungkan dan digunakan dikehidupan orang yang sedang belajar (siswa). Secara logika dapat dipahami dan dipastikan dapat mengikuti pembelajaran dengan serius apabila isi yang dipelajari dapat berkaitan dengan kehidupan sehari-hari dengan kalimat yang familiar di pendengaran kita. Melalui inovasi pendidikan inilah, diharapkan ada perbaikan dalam melakukan praktik pembelajaran ke arah yang lebih baik (Munro, 2005). Perlu diingat bahwa sebaik apapun model pembelajaran tersebut memiliki keberhasilan dalam membantu untuk membangun pembelajaran yang kondusif bagi peserta yang tergantung dalam kepiawaian pengajar dalam menerapkannya, keunggulan pembelajaran disebabkan oleh peranan guru yang bisa menentukan strategi pembelajaran yang efektif termasuk pada dalamnya menentukan model pembelajarana. (Cox, 2010)

Peneliti akan menekankan inovasi pendidikan terhadap efektivitas penerapan Kurikulum 2013 (KURTILAS), yang merupakan salah satu upaya untuk meningkatkan kualitas pendidikan sekaligus proses pembelajaran, sehingga menuntut adanya perubahan dalam pembelajaran. Fokus pembelajaranya bergeser atas apa yang sudah diajarkan kepada peserta didik kepada sebuah kompetensi yang telah dicapai oleh peserta didik. Oleh karena itu dibutuhkan adanya inovasi pendidikan yang dapat menjadikan seorang pendidik yang profesional dan memiliki strategi belajar mengajar yang sesuai sebagai upaya untuk membantu dan menguasi suatu kompetensi yang ditetapkan dan disesuai dengan kebutuhan saat ini. Hal ini sejalan dengan tujuan dalam penelitian ini, yaitu untuk mengidentifikasi adanya inovasi pendidikan terhadap efektivitas penerapan Kurikulum 2013.

\section{Metode Penelitian}

Metode dalam penelitian ini adalah metode yang terdapat penjelasan dalam menggunakan pendekatan kualitatif, maka analisa data yang dipakai adalah teknik analisis inferensial (inferential analitic) dari data-data, baik bahan-bahan literature, dokumen, dan sumber bacaan yang bertalian secara khusu dengan: Inovasi Pendidikan terhadap Efektivitas Penerapan Kurikulum 2013.(Suharsimi Arikunto, 1993). Menurut Singarimbun dan Effendi penelitian penjelasan (explanatory research) yang merupakan berbagai penelitian dalam menjelaskan dan menyoroti antara hubungan kausal dan menguji hipotesis sebelumnya. Sedangkan pendekatan kualitatif dimaksudkan bahwa dalam penelitian ini bersifat menerangkan (deskriftion) dan cenderung menggunakan analisis. Proses dan makna lebih ditonjolkan pada penelitian ini, sedangkan landasan teori, dimanfaatkan menjadi pemandu agar penekanan penelitian sesuai dengan fakta yang langsung berapa dilapangan. 


\section{Hasil dan Pembahasan}

\section{Konsep Inovasi Pendidikan}

Pada Kamus Lengkap Bahasa Indonesia (1997), penemuan berarti inovasi sesuatu yang baru atau tidak selaras menggunakan sesuatu yang telah terdapat sebelumnya. Sedangkan inovatif ialah memperkenalkan sesuatu yang baru. Pembelajaran ialah suatu proses aktivitas yang merupakan suatu pembelajaran bagi anak didik. Jadi, inovasi dalam sebuah pembelajaran ialah suatu kegiatan memperkenalkan pada sesuatu yang baru pada upaya membelajarkan siswa, atau memperkenalkan sesuatu yang baru dalam melakukan suatu tranfer pengetahuan, keterampilan, dan nilai-nilai pada siswa.(Kamisa, 1997)

Pengertian bukan berarti sesuatu yang baru, namun kita bisa mengambil sesuatu yang telah lama, kemudian dimodifikasi sedemikian rupa sampai menjadi sesuatu yang baru untuk diperkenalkan pada siswa. inovasi pembelajaran dapat dilakukan oleh seluruh komponen pembelajaran, seperti metode pendekatan, sarana prasarana di lingkungan sekolah, kurikulum, media dan lingkungan belajar. Pada pembelajaran aktif kreatif efektif serta menyenangkan, maka perlu menambahkan pembelajaran inovatif, sehingga menjadi inovatif dalam prinsip yang sesuai dengan yang diinginkan dalam KURIKULUM 2013.(Muharrom, 2008)

Bentuk pembelajaran tadi bisa dikemas dan dimunculkan pada setiap proses pembelajaran, baik sendiri-sendiri maupun campuran, diantaranya mengingat pada ruang gerak pengajar yang sangat dibatasi oleh jam pelajaran yang wajib dalam menyebarkan dengan mata pelajaran yang lain, maka hal yang sulit bagi seseorang guru adalah menerapkan beberapa pembelajaran secara bersama-sama.

Oleh karena itu seorang guru diharuskan dapat menciptakan sebuah inovasi pembelajaran yang bagus untuk kemauan dan keinginan yang dapat mengubah suatu image keterpaksaan menjadi suatu kebutuhan, dengan cara membawa anak untuk menikmati sisi-sisi dari sebuah keindahan dan kemenarikan dari suatu materi sedang dipelajarinya. Hal ini hanya dapat dilakukan abila guru melakukan sebuah inovasi dengan menggunakan prinsip pembelajaran yang bermakna dan menyenangkan. Melalui inovasi inilah, sangat diharapkan untuk memperbaiki praktik pembelajaran mejadi yang terbaik. Perbaikan pada sebuah proses itu sangat penting untuk menghasilkan pembelajaran yang berkualitas. (Sheal, 1989).

Pernyataan tadi nampak sejalan dengan yang dibutuhkan pada KURIKULUM 2013, yang menginginkan peserta didik mencapai suatu kompetensi tertentu yang dapat dikomunikasikan serta ditampilkan.(Prastowo, 2011). Dalam kurikulum terbaru menginginkan perubahan dalam pembelajaran. Perubahan ini tentunya tak semudah dengan yang diucapkan, sebab pola pembelajaran kita telah terbiasa dengan cara pengajar mengungkapkan serta menyampaikan berbagai informasi, sedangkan untuk siswa dapat menjadikannya lebih banyak menerima, tetapi tidak berate menjadi pesimis dalam menggunakan perubahan tadi, namun mungkin pencapaian dalam melakukan berubahan ini memerlukan waktu yang tidak sebentar. 
Dalam pelaksanaannya, pembelajaran yang bisa mendorong siswa aktif secara fisik, sosial, serta mental untuk memahami, menyebarkan dan menekankan suatu ilmu untuk menuju pembelajaran yang bersifat mandiri, serta berlatih, beraktivitas dengan memakai daya pikir, emosional, serta keterampilannya. Melalui pembelajaran aktif diharapkan siswa akan lebih bisa mengenal dan menyebarkan kapasitas belajar serta potensi yang dimilikinya. Selain itu, dapat memakai potensi sumber belajar yang ada di sekitarnya, lebih terlatih untuk berprakarsa, berpikir secara sistematis, kritis, tanggap, sehingga dapat merampungkan persoalan sehari-hari melalui penelusuran info yang bermakna baginya.

Pengajar yang aktif adalah pengajar yang memantau aktivitas belajar murid, memberi umpan balik, mengajukan pertanyaan yang menantang, dan memperbanyak gagasan siswa untuk bisa dimunculkan. Sedangkan anak didik yang aktif ialah mereka yang acapkali bertanya, mengemukakan pendapat, mempertanyakan gagasan orang lain dan gagasannya sendiri, serta aktif melakukan suatu aktivitas belajar.(Maspupah, 2018) Sayangnya, sebagian pengajar kurang bisa mengajukan pertanyaan yang menan-tang pada siswa, sebagai akibatnya pembelajaran aktifpun jarang tercipta. Hal ini kemungkinan ditimbulkan banyak sekali hal, seperti alasan klise sebab dikejar waktu untuk merampungkan materi hingga tidak sempat berpikir ke arah itu, ketidaksiapan guru itu sendiri untuk membuat serta menjawab pertanyaan menantang. (Kemendikbud, 2013)

\section{Konsep Kurikulum 2013}

Penyelenggaraan pendidikan sebagaimana yang telah diamanatkan pada Undangundang nomor 20 Tahun 2003 perihal Sistem Pendidikan Nasional diharapkan bisa mewujudkan proses berkembangnya kualitas langsung siswa sebagai generasi penerus bangsa pada masa depan, yang diyakini akan memberikan berbagai faktor bagi tumbuh kembangnya bangsa dan negara Indonesia sepanjang zaman.

Dari sekian banyaknya unsur sumber daya pendidikan, kurikulum merupakan salah satu unsur yang memberikan kontribusi yang signifikan untuk mewujudkan proses berkembangnya kualitas potensi siswa. Jadi tidak bisa disangkal lagi bahwa kurikulum yang dikembangkan menggunakan berbasis pada kompetensi sangat diperlukan menjadi instrumen untuk mengarahkan peserta didik sebagai: (1) manusia berkualitas yang mampu serta agresif menjawab tantangan zaman yang selalu berubah; (2) manusia terdidik yang beriman dan bertakwa pada tuhan yang Maha Esa, berakhlak mulia, sehat berilmu, cakap, kreatif, mandiri; dan (3) masyarakat negara yang demokratis serta bertanggung jawab.

Kurikulum sebagaimana yang ditegaskan pada Pasal 1 Ayat (19) Undang-undang nomor 20 Tahun 2003 merupakan seperangkat planning serta pengaturan yang dipergunakan menjadi pedoman penyelenggaraan aktivitas pembelajaran agar mencapai sebuah tujuan untuk pendidikan tertentu. Pengembangan Kurikulum 2013 merupakan lagkah untuk melanjutkan kepada Pengembangan Kurikulum Berbasis Kompetensi yang sudah dirintis pada tahun 2004 dan KTSP 2006 yang mencakup kompetensi perilaku, pengetahuan, serta keterampilan secara terpadu.(Mulyasa, 2013) 


\section{a. Tantangan Internal}

Tantangan internal diantaranya terkait dengan adanya beberapa kondisi pendidikan yang dikaitkan dengan tuntutan untuk mengacu kepada 8 (delapan) standar Nasional Pendidikan yang mencakup standar pengelolaan, standar biaya, standar sarana prasarana, standar pendidik serta energi kependidikan, standar isi, standar proses, standar penilaian, serta standar kompetensi lulusan. Tantangan internal lainnya yaitu memiliki keterkaitan dengan faktor perkembangan penduduk di Indonesia yang sudah ditinjau dari usia produktif. Terkait tantangan internal pertama, banyak aktivitas yang dilaksanakan dalam mengupayakan penyelenggara pendidikan agar dpat mencapai ke delapan standar yang sudah ditetapkan. Hal ini sebagaimana terlihat dalam Tabel di bawah ini:

\section{Gambar 1}

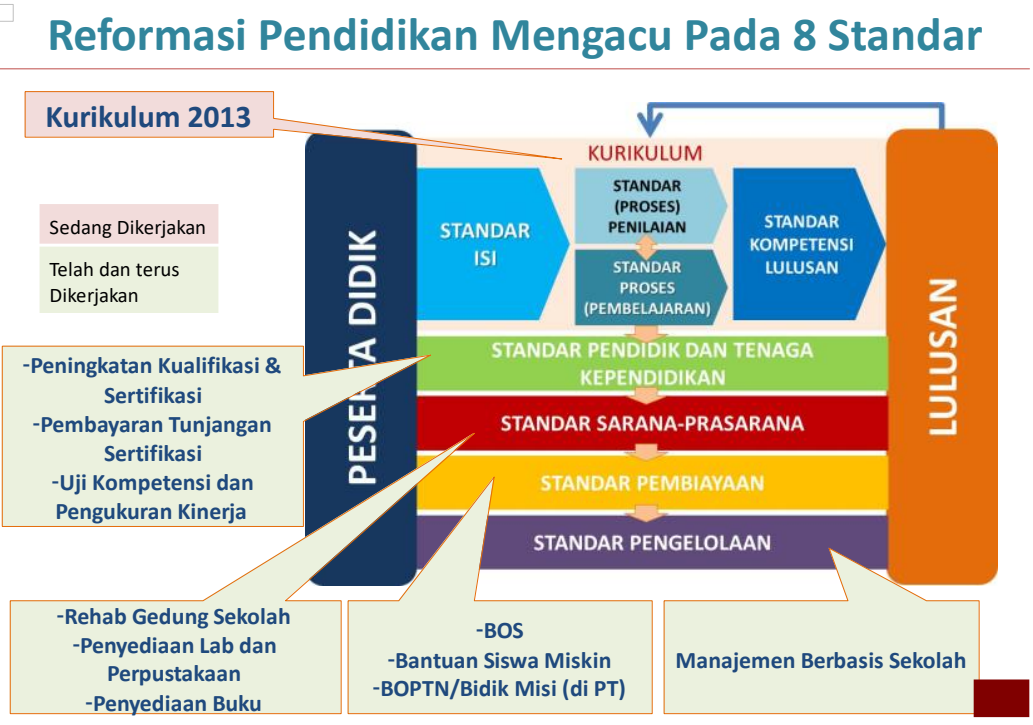

Terkait perkembangan Sumber Daya Manusia (SDM) dengan usia produktif yang besar, memiliki kompetensi dalam menerampilkan modal pembangunan yang luar biasa besarnya. Namun apabila tidak memiliki dasar keterampilan dan kompetensi, tentunya dapat menjadikan beban dalam pembangunan. Oleh sebab itu ada beberapa tantangan besar yang akan dihadapi adalah bagaimana cara dalam mengupayakan sumber usia yang produktif dan melimpah yang dapat ditransformasikan menjadi Sumber Daya Manusia (SDM) yang memiliki kompetensi dan keterampilan melalui beberapa pendidikan agar tidak menjadi beban. Hal ini dapat kita lihat dalam Tabel dibawah ini: 


\section{Gambar 2}

Bonus Demografi Sebagai Modal
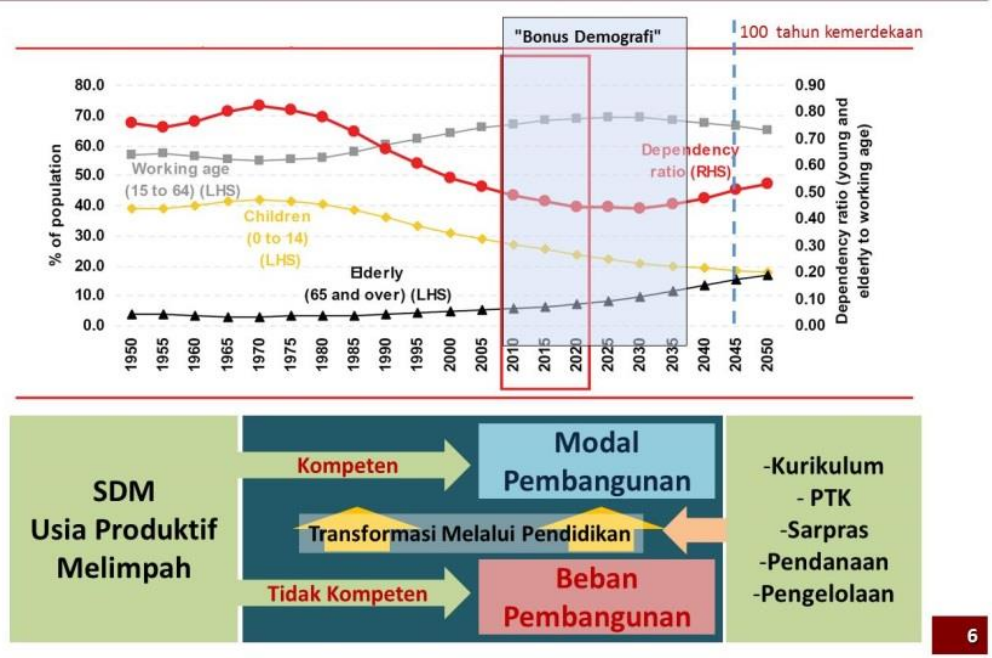

\section{b. Tantangan Eksternal}

Tantangan eksternal yang akan dihadapi dalam suatu pendidikan antara lain yang dapat berkaitan dengan masa depan, kompetensi yang akan diperlukan di masa depan adalah melalui persepsi masyarakat, perkembangan dengan menggunakan pengetahuan dan pedagogi, serta berbagai fenomena negatif yang mengemuka, sebagaimana terlihat pada Tabel tekanan untuk pengembangan kurikulum di bawah ini:

\section{Tabel 3}

\section{Tekanan Untuk Pengembangan Kurikulum}

\begin{tabular}{|c|c|}
\hline Tantangan Masa Depan & Kompetensi Masa Depan \\
\hline \multirow{3}{*}{$\begin{array}{l}\text { - Globalisasi: WTO, ASEAN Community, APEC, CAFTA } \\
\text { - Masalah lingkungan hidup } \\
\text { - Kemajuan teknologi informasi } \\
\text { - Ekonomi bensi ilmu dan teknologi } \\
\text { - Kebangkitan industri kreatif dan budaya } \\
\text { - Pergeseran kekuatan ekonomi dunia } \\
\text { - Pengaruh dan imbas teknosains } \\
\text { - Mutu, investasi dan transformasi pada sektor } \\
\text { - Materikan } \\
\text { PersepsiMS dan PISA } \\
\text { - Terlalu menitikberatkan pada aspek kognitif } \\
\text { - Beban siswa terlalu berat } \\
\text { - Kurang bermuatan karakter }\end{array}$} & $\begin{array}{l}\text { - Kemampuan berkomunikasi } \\
\text { - Kemampuan berpikir jernih dan kritis } \\
\text { - Kemampuan mempertimbangkan segi moral suatu } \\
\text { - Kemampuan menjadi warga negara yang bertanggungjawab } \\
\text { - Kemampuan mencoba untuk mengerti dan toleran terhadap } \\
\text { pandangan yang berbeda } \\
\text { - Kemampuan hidup dalam masyarakat yang mengglobal } \\
\text { - Memiliki minat luas dalam kehidupan } \\
\text { - Memiliki kesiapan untuk bekerja } \\
\text { - Memiliki kecerdasan sesuai dengan bakat/minatnya } \\
\text { - Memiliki rasa tanggungjawab terhadap lingkungan }\end{array}$ \\
\hline & Fenomena Negatif yang Mengemuka \\
\hline & $\begin{array}{l}\text { §Perkelahian pelajar } \\
\text { §Narkoba }\end{array}$ \\
\hline Perkembangan Pengetahuan dan Pedagogi & $\begin{array}{l}\text { §Korupsi } \\
\text { §Plagiarisme } \\
\text { §Kecurangan dalam Ujian (Contek, Kerpek..) }\end{array}$ \\
\hline $\begin{array}{l}\text { - Neurologi } \\
\text { - Psikologi }\end{array}$ & $\S$ Gejolak masyarakat (social unrest) \\
\hline
\end{tabular}

\section{c. Penyempurnaan Pola Pikir}

Pendidikan yang sesuai untuk kebutuhan di masa depan dapat terwujud apabila terjadi pergeseran atau perubahan pola pikir. Pergeseran itu meliputi proses pembelajaran sebagai berikut: 
1. Dari berpusat pada guru menuju berpusat pada siswa.

2. Dari satu arah menuju interaktif.

3. Dari isolasi menuju lingkungan jejaring.

4. Dari pasif menuju aktif-menyelidiki.

5. Dari maya/abstrak menuju konteks dunia nyata.

6. Dari pembelajaran pribadi menuju pembelajaran berbasis tim.

7. Dari luas menuju perilaku khas memberdayakan kaidah keterikatan.

8. Dari stimulasi rasa tunggal menuju stimulasi ke segala penjuru.

9. Dari alat tunggal menuju alat multimedia.

10. Dari hubungan satu arah bergeser menuju kooperatif.

11. Dari produksi massa menuju kebutuhan pelanggan.

12. Dari usaha sadar tunggal menuju jamak.

13. Dari satu ilmu pengetahuan bergeser menuju pengetahuan disiplin jamak.

14. Dari kontrol terpusat menuju otonomi dan kepercayaan.

15. Dari pemikiran faktual menuju kritis.

16. Dari penyampaian pengetahuan menuju pertukaran pengetahuan.

Sejalan itu, perlu dilakukannya penyempurnaan terhadap pola pikir dalam penggunaan pendekatan baru pada perumusan Standar Kompetensi Lulusan. Perumusan SKL di dalam KBK 2004 dan KTSP 2006 yang diturunkan dari Standar Isi (SI) harus diubah menjadi perumusan yang diturunkan dari kebutuhan. Pendekatan dalam penyusunan SKL pada KBK 2004 dan KTSP 2006. Sedangkan pada Kurikulum 2013 diturunkan dari kebutuhan atau Standar Kopetensi Lulusan (SKL), sebagaimana dapat dilihat pada bagan Tabel Penyempurnaan Pola Pikir Perumusan Kurikulum di bawah ini:

Gambar 4

\begin{tabular}{|c|c|c|c|}
\hline No & KBK 2004 & KTSP 2006 & Kurikulum 2013 \\
\hline 1 & \multicolumn{2}{|c|}{$\begin{array}{l}\text { Standar Kompetensi Lulusan diturunkan dari } \\
\text { Standar Isi }\end{array}$} & $\begin{array}{l}\text { Standar Kompetensi Lulusan } \\
\text { diturunkan dari kebutuhan }\end{array}$ \\
\hline 2 & \multicolumn{2}{|c|}{$\begin{array}{l}\text { Standar Isi dirumuskan berdasarkan Tujuan } \\
\text { Mata Pelajaran (Standar Kompetensi Lulusan } \\
\text { Mata Pelajaran) yang dirinci menjadi Standar } \\
\text { Kompetensi dan Kompetensi Dasar Mata } \\
\text { Pelajaran }\end{array}$} & $\begin{array}{l}\text { Standar Isi diturunkan dari } \\
\text { Standar Kompetensi Lulusan } \\
\text { melalui Kompetensi Inti yang } \\
\text { bebas mata pelajaran }\end{array}$ \\
\hline 3 & \multicolumn{2}{|c|}{$\begin{array}{l}\text { Pemisahan antara mata pelajaran pembentuk } \\
\text { sikap, pembentuk keterampilan, dan } \\
\text { pembentuk pengetahuan }\end{array}$} & $\begin{array}{l}\text { Semua mata pelajaran harus } \\
\text { berkontribusi terhadap } \\
\text { pembentukan sikap, keterampilan, } \\
\text { dan pengetahuan, }\end{array}$ \\
\hline 4 & \multicolumn{2}{|c|}{ Kompetensi diturunkan dari mata pelajaran } & $\begin{array}{l}\text { Mata pelajaran diturunkan dari } \\
\text { kompetensi yang ingin dicapai }\end{array}$ \\
\hline 5 & \multicolumn{2}{|c|}{$\begin{array}{l}\text { Mata pelajaran lepas satu dengan yang lain, } \\
\text { seperti sekumpulan mata pelajaran terpisah }\end{array}$} & $\begin{array}{l}\text { Semua mata pelajaran diikat oleh } \\
\text { kompetensi inti (tiap kelas) }\end{array}$ \\
\hline
\end{tabular}

\section{d. Penguatan Tata Kelola Kurikulum}

Pada Kurikulum 2013, penyusunan dimulai dengan mereapkan dan menetapkan standar kompetensi lulusan, tujuan pendidikan nasional, serta kebutuhan. setelah kompetensi ditetapkan kemudian ditentukan kurikulumnya yang terdiri dari kerangka dan struktur kurikulum. Satuan pendidikan serta pengajar tidak diberikan wewenang menyusun silabus, akan tetapi disusun pada taraf nasional. 
Pengajar lebih diberikan kesempatan untuk mengembangkan suatu proses pembelajaran tanpa beban dan penyusunan silabus yang memakan waktu banyak serta memerlukan penguasaan teknis penyusunan yang sangat memberatkan bagi pengajar. Perbandingan kerangka kerja penyusunan kurikulum bisa dicermati di Tabel dibawah ini:

\section{Gambar 5}

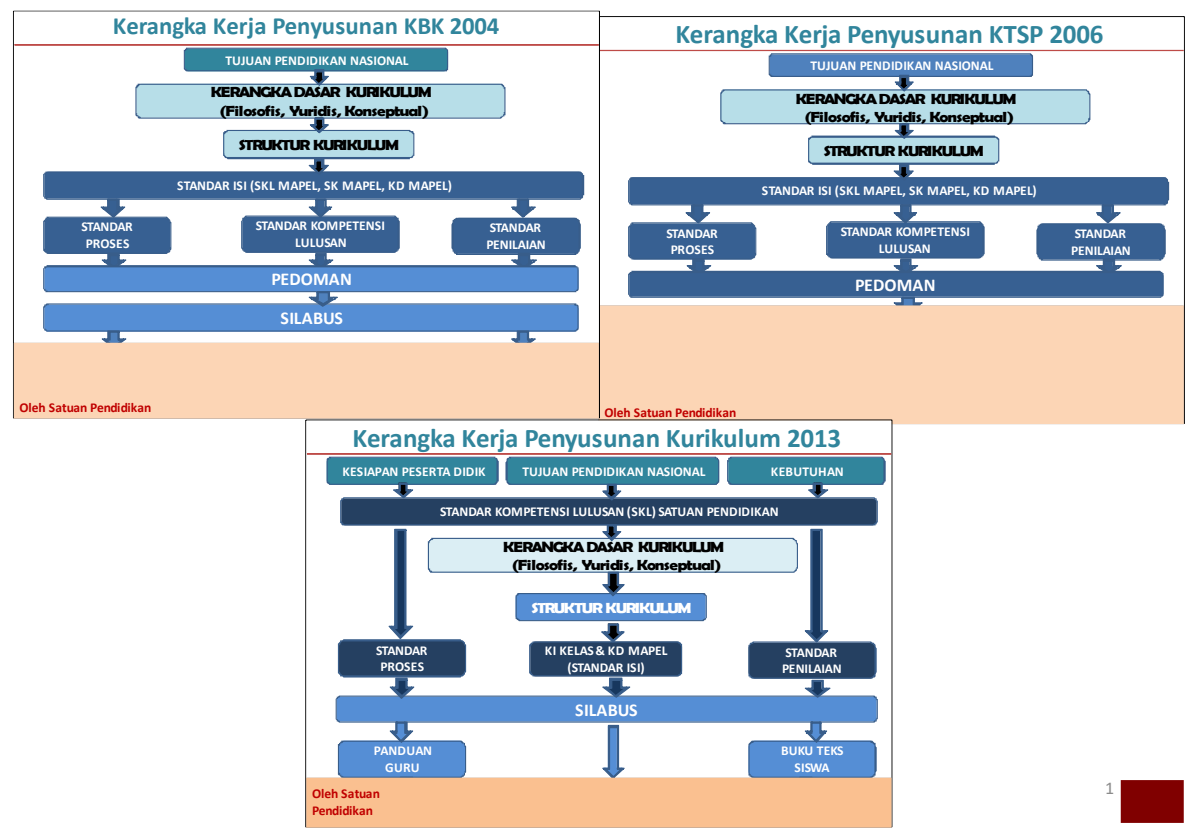

Hasil monitoring serta penilaian pelaksanaan kurikulum yang dilakukan menunjukkan bahwa total saat pembelajaran yang dialokasikan oleh banyak pengajar untuk beberapa mata pelajaran di Sekolah Dasar, SMP, serta Sekolah Menengan Atas lebih kecil dari total waktu pembelajaran yang dialokasikan menurut standar isi. Pada kesulitan yang dihadapi pengajar dalam melaksanakan Kurikulum 2013, kemungkinan terdapat waktu yang dialokasikan pada standar yang tidak dapat dilaksanakan sepenuhnya. Hasil monitoring serta penilaian ini menunjukkan bahwa terdapat banyaknya kompetensi yang sulit dipahami guru, serta jika diajarkan pada peserta didik sulit dicapai oleh peserta didik. Rumusan kompetensi ini juga sulit dijabarkan kepada indikator pembelajaran.

Dalam ketercapaian untuk memiliki kompetensi sesuai dengan yang telah ditetapkan agar dapat mempermudah pemantauan serta pengawasan aplikasi pengajaran, perlu mengambil langkah dalam memperkuat tata kelola antara lain dengan menyiapkan buku pegangan pembelajaran siswa dan buku pegangan pengajar. Sebab pengajar ialah faktor yang sangat penting di dalam pelaksanaan kurikulum, maka sangat penting untuk menyiapkan pengajar agar tahu pemanfaatan sumber belajar yang sudah disiapkan serta sumber lain yang bisa mereka manfaatkan. Untuk menjamin keterlaksanaan dan pengimplementasi kurikulum dan aplikasi pembelajaran, juga perlu diperkuat peran pendampingan serta pemantauan oleh pusat serta daerah.(Syatibi, 2015) 


\section{Inovasi Pendidikan Terhadap Efektivitas Penerapan Kurikulum 2013}

Sebagaimana diketahui, bahwa sekarang telah menerapkan kurikulum baru yaitu Kurikulum 2013 (KURTILAS), di mana hal ini merupakan konsep kurikulum yang meletakkan pada posisi yang paling dekat dengan pembelajaran yaitu sekolah dan satuan pendidikan, dengan memberikan sesuatu yang lebih besar dengan sikap tanggap pemerintah terhadap tuntutan masyarakat juga merupakan sarana peningkatan kualitas, efisiensi dan pemerataan pendidikan. Dengan di terapkanya Kurikulum 2013 (KURTILAS) yang merupakan salah satu upaya untuk meningkatkan kualitas pendidikan sekaligus proses pembelajaran, sehingga menuntut adanya perubahan dalam suatu proses penyampaian pembelajaran.

Fokus pembelajaranya bergeser dengan apa yang diajarkan kepada peserta didik ke arah kompetensi apa yang telah atau yang akan dicapai oleh peserta didik. Oleh karena itu dibutuhkan seorang pendidik yang profesional sesuai dengan kebutuhan saat ini. Mengajar dalam pemahaman itu memerlukan strategi belajar mengajar yang sesuai sebagai upaya untuk membantu peserta didik dalam menguasai kompetensi yang ditetapkan.(Mulyoto, 2013)

Pembelajaran ialah suatu kombinasi yang mencakup pada unsur-unsur manusiawi guna mencapai tujuan pembelajaran. Pembelajaran pada hakikatnya ialah proses dalam menginteraksikan antara peserta didik dengan lingkungan sekitar, sehingga terjadi perubahan sikap ke arah yang lebih baik. Pada interaksi itu terdapat berbagai faktor yang mempengaruhi baik faktor internal juga faktor eksternal yang berdatangan dari lingkungan pembelajaran, serta tugas pengajar yang utama ialah mengkondisikan berbagai lingkungan untuk menunjang terjadinya perubahan prilaku bagi siswa.

Dengan demikian peranan guru dalam melakukan metode pembelajaran adalah menentukan kualitas pembelajaran, oleh karena itu guru perlu meningkatkan kemampuan profesionalisme dalam pembelajaran, sehingga proses pembelajaran dapat mencapai suatu tujuan yang diinginkan. Setiap manusia pasti mempunyai ketertarikan serta rasa ingin tahu yang tinggi terhadap sesuatu yang baru. Demikian pula siswa, bila dalam pembelajaran disuguhi sesuatu yang baru, dipastikan dapat memiliki semangat baru dalam mengikuti pelajaran. dengan istilah lain, sesuatu yang baru bisa bertindak seperti magnet yang menarik minat serta motivasi siswa untuk mengikutinya.

Inovatif pendidikan terhadap efektivitas penerapan Kurikulum 2013 ialah suatu pembelajaran untuk memperkenalkan apa yang belum dialami dari sebelumnya. Sesuatu yang baru tidak identik menggunakan sesuatu yang baru dan agak sepele nampaknya sepele, bisa jadi mampu membuat pembelajaran lebih hidup hanya sebab oleh pengajar bisa melakukan inovasi. pada penciptaan pembelajaran inovatif yang terpenting ialah kemauan serta harapan pengajar untuk membuat belajar menjadi menarik untuk diikuti serta menghilangkan kebosanan peserta didik dalam belajar. sehingga tumbuh kretivitas. Kreatif merupakan cara berfikir dengan mengajak untuk keluar serta melepaskan diri dari pola umum yang telah terpateri pada ingatan. Pembelajaran kreatif ialah pembelajaran yang mengajak siswa untuk mampu membentuk sesuatu yang di luar pemikiran orang kebanyakan. 
Terlepas dari suatu yang telah terencana pada pikiran kita bukanlah pekerjaan yang simpel. Beberapa hal dapat membangkitkan pikiran untuk menjadi kreatif diantaranya: berfantasi atau mengemukakan gagasan untuk beberapa saat, berani mengambil resiko, memiliki kepekaan dalam suatu kejaiban, mempertanyakan terhadap suatu keneraran, dan memperbanyak membaca sebuah artikel yang memiliki inovasi sehingga dapat menjadi kagum.

Untuk bisa membangun pembelajaran inovatif juga kreatif dibutuhkan 3 sifat dasar yang harus dimiliki seorang pelajar ataupun pengajar, yaitu peka, kritis, serta kreatif terhadap kenyataan yang terdapat di sekitarnya. Peka ialah orang lain yang tidak bisa melihat beberapa kaitan dengan konsep yang terdapat dalam otak, namun kita mampu menangkapnya sebagai kenyataan yang bisa dijelaskan menggunakan konsep yang kita miliki. Kritis ialah sebuah fenomena yang tertangkap oleh mata kita, dan dijadikan olah pikiran hingga memunculkan banyak pertanyaan yang menjadikan kita untuk mencari jawabannya.

Sebagai contoh, seseorang pengajar Sekolah Dasar bisa meminta anak didiknya menyimpulkan sifat benda cair hanya dengan meminta semua anak didiknya mengisi air ke pada gelas plastik yang beraneka ragam bentuknya. seorang pengajar IPS Sekolah Menengah Pertama menanamkan suatu pemahaman dari jenis dan motif sebuah ekonomi dengan menghasilkanapa yang dimainkan oleh anak didik yang ditebak oleh sitap anak.

Guru yang kreatif serta inovatif merupakan guru yang mampu membuat sebuah aktivitas yang beragam, menghasilkan alat bantu/media sederhana yang bisa dirancang sendiri oleh anak didiknya. Demikian juga siswa yang kreatif serta inovatif yang dapat merancang, menulis dan mengarang sesuatu, serta menghasilkan refleksi terhadap seluruh aktivitas yang dilakukannya.

Efisien memiliki arti pas ialah suatu yang memiliki imbas/ dampak terhadap yang hendak dicapai/ dituju. Pendidikan efisien menggambarkan pendidikan yang sanggup mencapai kompetensi yg sudah diformulasikan, pendidikan dimana murid mendapatkan pengetahuan, keahlian, serta perilaku. Pendidikan dikatakan efisien Apabila terjalin pergantian di aspek kognitif, afektif, serta psikomotor.

Ada pula identitas pendidikan efisien antara lain tercapainya tujuan yang diharapkan, anak didik memahami keahlian yang ditargetkan. Belajar serta mengajar hendak efisien bila anak didik aktif serta seluruh kegiatan pendidikan berpusat pada anak didik. Perihal ini sebab pendidikan yang berpusat pada anak didik hendak sanggup memunculkan minatnya serta secara tidak langsung mereka menguasai konsep serta kaitannya dengan aspek- aspek kehidupan.

Dikala ini di berbagai negara tengah trend dan semangat mengembangkan joyful learning dan meaningful learning, yakni dengan menciptakan keadaan pembelajaran sede- mikian rupa sehingga anak didik menjadi betah di kelas karena pendidikan yang dijalani menyenangkan serta bermakna. Mereka merasakan bahwa pembelajaran yang dijalani memberikan perbedaan dalam basis pengetahuan yang terselip di pikirannya, berbeda dalam memandang dunia sekitar, serta merasakan mendapatkan suatu yang 
lebih dari apa yang sudah dimilikinya selama ini. Sebagai bangsa yang ingin maju dalam masa globalisasi yang kompetitif ini pastinya kita pula mau merasakan pendidikan yang demikian.

Seluruh mata pelajaran sanggup dibuat menjadi menyenangkan, tergantung bagaimana kemauan serta keinginan guru buat menciptakannya. Pendidikan yang dikemas dalam situasi yang mengasyikkan, jenaka, serta menggelitik sangat diharapkan oleh anak didik disaat ini yang sangat rawan stres sebab saratnya materi ajar yang mesti dipahami. Riset terhadap sebagian anak- anak sekolah di dunia yang diadakan UNESCO menampilkan sebagian dari mereka menginginkan belajar dengan suasana yang menyenangkan (Dedi Supriadi, 1999)

Pendidikan yang menyenangkan artinya pembelajaran yang interaktif dan atraktif, sehingga anak didik sanggup memusatkan atensi terhadap pembelajaran yang sedang dijalaninya. Studi menunjukkan bahwa pada saat seorang guru memaparkan sesuatu materi tanpa ada selingan serta anak didik hanya mencermati, memandang, serta mencatat, hingga atensi serta konsentrasi mereka hendak menyusut secara draktis sehabis 20 menit. Kondisi ini terus menjadi parah bila guru tidak menyadari serta pendidikan cuma berjalan monoton serta membosankan. Lebih lanjut dikemukakan, kondisi ini bisa diatasi apabila guru menyadari kemudian mengganti pembelajarannnya jadi mengasyikkan dengan metode berikan selingan kegiatan ataupun humor. Aksi ini secara signifikan mempengaruhi tingkatkan kembali atensi serta konsentrasi anak didik yang relatif besar.

Pendidikan menyenangkan merupakan pendidikan yang membuat anak didik tidak khawatir salah, ditertawakan, diremehkan, tertekan, namun kebalikannya anak didik berani berbuat serta berupaya, bertanya, mengemukakan komentar/ gagasan, serta mempertanya- kan gagasan orang lain. Menghasilkan atmosfer yang mengasyikkan bukanlah susah, sebab kita cuma menghasilkan pendidikan yang relaks( tidak tegang), lingkuangan yang nyaman buat melaksanakan kesalahan, mengaitkan modul ajar dengan kehidupan mereka, belajar dengan balutan humor, dorongan semangat, serta pemberian sela waktu berpikir.

Cocok dengan komentar Ausubel( 2001) kalau belajar hendak bermakna bila partisipan didik bisa mengaitkan konsep yang dipelajari dengan konsep yang telah terdapat dalam struktur kognitifnya, serta komentar Bruner(2002) yang melaporkan belajar hendak sukses lebih baik bila senantiasa dihubungkan dengan kehidupan orang yang lagi belajar. Secara logika bisa dimengerti, kalau kita tentu hendak belajar sungguh- sungguh apabila yang dipelajari terdapat kaitannya dengan kehidupan tiap hari serta perkata ataupun kalimat yang didengar telah sering di dengar di kepala kita. Lewat joyful learning diharapkan terdapat revisi aplikasi pendidikan ke arah yang lebih baik. Pergantian ini tidak wajib terjalin secara draktis, lambat- laun namun tentu. Revisi proses sangat berarti supaya keluaran yang dihasilkan betul- betul bermutu.

Semacam diketahui, otak kita dipecah menjadi 2 bagian, ialah kanan dan kiri. Terkadang dalam dunia pembelajaran kita kurang ingat hendak pentingnya meningkatkan otak sebelah kanan. Secara umum hanya otak kiri yang jadi target 
pengembangan, paling utama buat ilmu eksakta. Otak sebelah kanan merupakan bagian yang berkaitan dengan imajinasi, estetika, intuisi, irama, musik, foto, seni. Kebalikannya otak sebelah kiri berkaitan dengan logika, rasio, penalaran, perkata, matematika, serta urutan. Sesungghnya kita bisa tunjukkan apabila ilmu yang didapat sanggup digunakan untuk meningkatkan otak sebelah kanan, antara lain dengan metode menguasai serta menghafal konsep lewat puisi, nyanyian, ataupun game teka- teki.

Otak kita merupakan bagian badan yang sangat rawan serta sensitif. Otak sangat menggemari hal- hal yang bersifat tidak masuk akal, ekstrim, penuh corak, lucu, multisenso- rik, foto 3 ukuran (hidup), asosiasi, imajinasi, simbol, mengaitkan irama/ musik, serta no/ urutan. Bersumber pada perihal ini, hingga kita bagaikan pendidik bisa merancang apa yang hendaknya kita bagikan kepada anak didik agar otak mereka dapat menyukainya.

Efisien mempunyai arti pas, guna maksudnya suatu yang mempunyai dampak/ pengaruh terhadap yang hendak dicapai/ dituju. Pendidikan efisien maksudnya pendidikan yang sanggup menggapai kompetensi yang sudah diformulasikan, pendidikan dimana anak didik mendapatkan pengetahuan, keahlian, serta perilaku. Pendidikan dikatakan efisien bila terjalin pergantian pada aspek kognitif, afektif, serta psikomotor.

Ada pula identitas pendidikan efisien antara lain tercapainya tujuan yang diharapkan, anak didik memahami keahlian yang ditargetkan. Belajar serta mengajar hendak efisien bila anak didik aktif serta seluruh kegiatan pendidikan berpusat pada anak didik. Perihal ini sebab pendidikan yang berpusat pada anak didik hendak sanggup memunculkan minatnya serta secara tidak langsung mereka menguasai konsep serta kaitannya dengan aspek- aspek kehidupan. Inovasi itu mempunyai makna pembaharuan yang berdekatan dengan perubahan atau perbaikan. Perubahan adalah pergeseran posisi.

Peran, ataupun kondisi yang memungkinkan membawa kearah kebaikan, namun kadangkala juga membawa kebaikan. (Zaini, 2006)Perbaikan kurikulum umumnya hanya menimpa satu ataupun sebagian aspek dari kurikulum, misalnya tata cara mengajar, perlengkapan peraga, novel pelajaran dengan senantiasa mengguankan kurikulum yang berlaku. Pergantian kurikulum menimpa pergantian dasar- dasarnya baik menimpa tujuan ataupun alat- alat ataupun cara- cara menggapai tujuan itu. Mengganti kurikulum berarti ikut mengganti manusia ialah guru, pembina pembelajaran serta merek- merek yang mengurus pembelajaran. Itu sebabnya kurikulum dikira bagaikan pergantian sosial, sesuatu social change.

Pergantian dalam sebuah kurikulum, dapat diucapkan dengan pembaruan ataupun penemuan kurikulum, pasti saja bermaksud untuk buat menggapai revisi (Nasution, 1999).Perubahan dan pembaharuan oleh kurikulum itu mempunyai beberapa faktor yang harus dilibatkan. Antara lain tidak mungkin dengan adanya perubahan kurikulum bisa berjalan tanpa diikuti oleh seluruh komponen sistem yang mendukung perubahan kurikulum itu itu senditi, atau pembaharuan kurikulum selama dapat dipastikan untuk menstrukturisasikan kurikulum yang ada untuk diganti dengan yang baru. Dalam 
kurikulum 2013 yang berbasis karakter dan kompetensi, asumsi merupakan parameter untuk memilih tujuan dan kompetensi yang akan dispesifikasikan.

\section{Kesimpulan}

Berdasarkan pembahasan di atas dapat disimpulkan: Pertama, Inovasi Pendidikan Terhadap Efektivitas Penerapan Kurikulum 2013 dipengaruhi oleh berbagai macam faktor, semisal: kondisi geografis, kondisi iklim organisasi dan pergaulan, kondisi alam sekitar serta dukungan, atau partisipasi masyarakat yang cukup kondusif. Kedua, In-put adanya Inovasi Pendidikan Terhadap Efektivitas Penerapan Kurikulum 2013 sesuai dengan peraturan dan kebijakan (policy) pemerintah dan tuntutan masyarakat untuk kemajuan pendidikan yang baik. Ketiga, out-put Inovasi Pendidikan Terhadap Efektivitas Penerapan Kurikulum 2013 merupakan bentuk evaluasi pendidikan, yang dalam hal ini dapat diketahui dari prestasi akademik, baik berupa nilai mata pelajaran dan nilai rapor, serta prestasi kademik siswa cukup baik dan mengalami peningkatan dari tahun ke tahun. Demikian juga dengan prestasi non akademik yang menunjukan hasil yang signifikan. Keempat, Out-come Inovasi Pendidikan Terhadap Efektivitas Penerapan Kurikulum 2013 merupakan bentuk penerapan pendidikan dengan upaya melibatkan semua stakeholder dalam kegiatan pendidikan setiap elemen, guru, siswa, sekolah, pemerintah, masyarat, serta tidak terbatas pada pengambilan keputusan yang berkaitan dengan program dan pendanaan pendidikan, baik negeri maupun swasta. 


\section{BIBLIOGRAFI}

Cox, G. (2010). Sustaining innovations in educational technology: Views of innovators at the University of Cape Town. Curriculum, Technology \& Transformation for an Unknown Future. Proceedings Ascilite Sydney, 240-243.

Kamisa. (1997). Kamus Lengkap Bahasa Indonesia.

Kemendikbud. (2013). Materi Implementasi Kurikulum 2013.

Maspupah, U. (2018). Pengembangan Kurikulum di Lembaga Pendidikan Anak Usia Dini. Yinyang: Jurnal Studi Islam Gender Dan Anak, 13(1), 133-135.

Muharrom, T. (2008). Metodologi PAKEM. Artikel Pendidikan.

Mulyasa, E. (2013). Pengembangan dan Impelemtasi Kurikulum 2013.

Mulyoto. (2013). Strategi Pembelajaran di Era Kurikulm 2013.

Munro, C. R. (2005). Best practices. Teaching and Learning: Challenging Current Paradigms and Redefining Their Role in Education. The College Quarterly, 8(3), $1-7$.

Nasution, S. (1999). Asas-asas kurikulum. Bumi Aksara.

Prastowo, A. (2011). Panduan kreatif membuat bahan ajar inovatif. Yogyakarta: DIVA press.

Sheal, P. (1989). Classroom observation: training the observers. ELT Journal, 43(2), 92-104.

Silberman, M. (2009). Active learning: 101 strategi pembelajaran aktif. Yogyakarta: Pustaka Insan Madani.

Suharsimi Arikunto. (1993). Prosedur Penelitian Suatu Pendekatan Praktis.

Supriadi, D. (2002). Internet masuk sekolah: Pemberdayaan guru dan mahasiswa dalam era sekolah berbasis e-learning. Seminar Implementasi E-Learning Untuk Sekolah Menengah. Bandung: PT. Telkom.

Supriadi, Dedi. (1999). Mengangkat citra dan martabat guru. Adicita Karya Nusa. 
Redmon Windu Gumati

Syatibi, R. R. (2015). Pengembangan dan Inovasi Kurikulum.

Wahyudin, D., \& Kurniasih, Tatang Saripudin, O. S. (n.d.). Pengantar Pendidikan (ed. 1 cet. 1$)$.

Zaini, M. (2006). Pengembangan kurikulum: konsep implementasi evaluasi dan inovasi. Penerbit eLKAF. 